듬 SCHOOL of GRADUATE STUDIES

EAST TENNESSEE STATE UNIVERSITY
East Tennessee State University Digital Commons@ East Tennessee State University

$5-2012$

\title{
The Impact on Student Learning Outcomes of Video When Used as a Primary Teaching Tool in the Internet Hybrid Classroom
}

Richard Sykes

East Tennessee State University

Follow this and additional works at: https://dc.etsu.edu/etd

Part of the Educational Methods Commons

\section{Recommended Citation}

Sykes, Richard, "The Impact on Student Learning Outcomes of Video When Used as a Primary Teaching Tool in the Internet Hybrid Classroom" (2012). Electronic Theses and Dissertations. Paper 1517. https://dc.etsu.edu/etd/1517

This Thesis - Open Access is brought to you for free and open access by the Student Works at Digital Commons @ East Tennessee State University. It has been accepted for inclusion in Electronic Theses and Dissertations by an authorized administrator of Digital Commons@ East Tennessee State

University. For more information, please contact digilib@etsu.edu. 
The Impact on Student Learning Outcomes of Video

When Used as a Primary Teaching Tool in the Internet Hybrid Classroom

\author{
A thesis \\ presented to \\ the faculty of the Department of Engineering Technology \\ East Tennessee State University
}

In partial fulfillment

of the requirements for the degree

Masters of Science in Engineering Technology

by

Richard Sykes

May 2012

Dr. Keith Johnson, Chair

Dr. Andy W. Clark

Todd Emma

Keywords: video, impact on student learning outcomes, online hybrid classroom 


\author{
ABSTRACT \\ The Impact on Student Learning Outcomes of Video \\ When Used as a Primary Teaching Tool in the Internet Hybrid Classroom \\ by \\ Richard Sykes
}

With increasing concern over the state of the education system in the United States, more and more emphasis is being placed on teaching methods. Internet related infrastructure has become cheaper and more powerful, and online learning environments are taking a stronger presence in most higher education institutions with more video content being sought for these environments. However, the effectiveness of using video as a teaching tool is still uncertain. Without additional research, video remains an expensive gamble for an already struggling system. The purpose of this study is to evaluate the impact on student learning outcomes of video content as a primary teaching method compared to more traditional lecture based classes. 


\section{CONTENTS}

Page

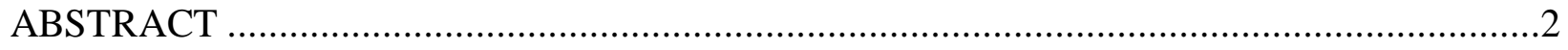

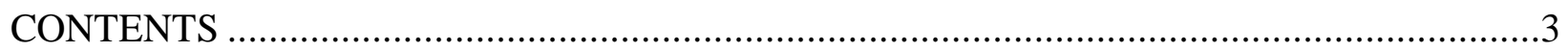

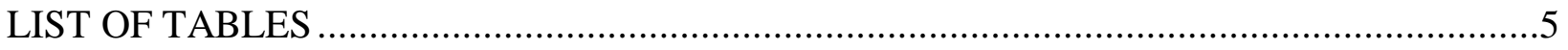

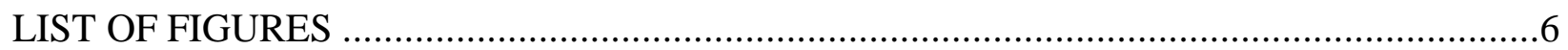

Chapter

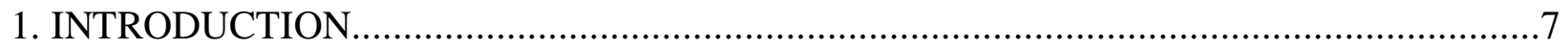

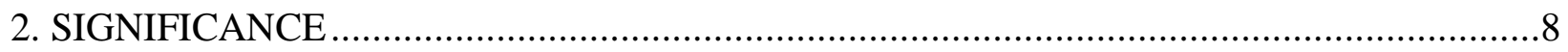

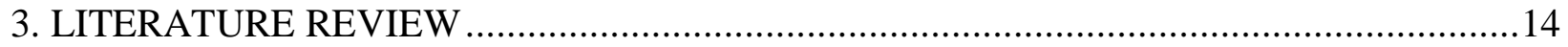

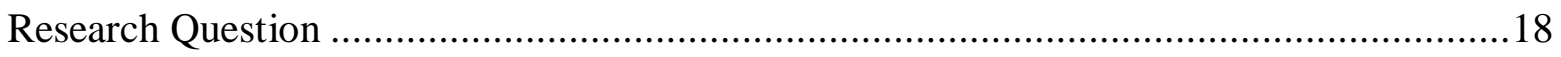

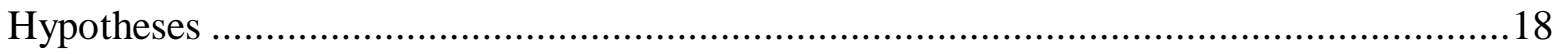

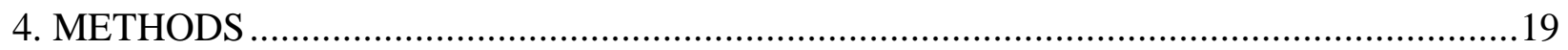

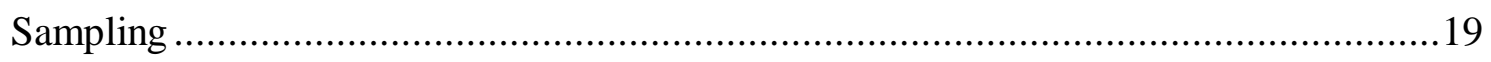

Experimental Setting ……………….............................................................19

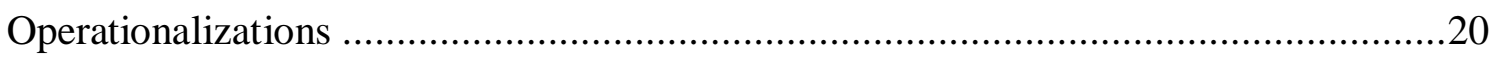

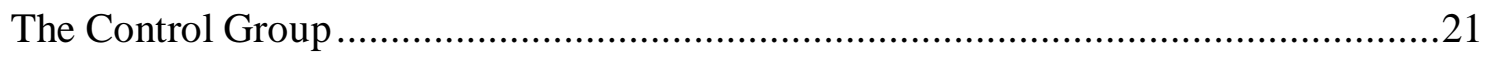

The Experimental Group ……………………….................................................22

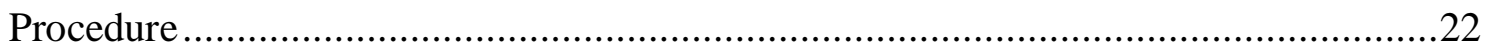

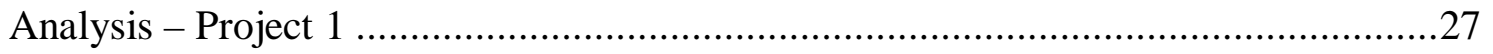

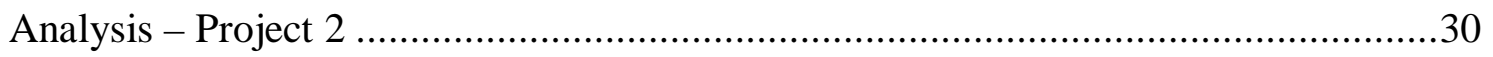

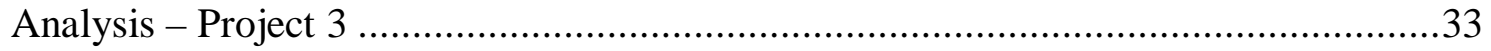

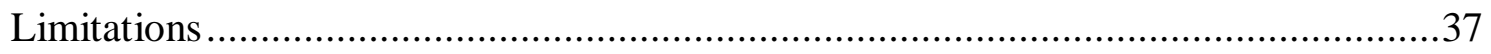




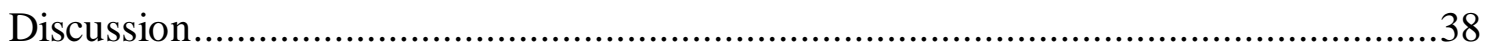

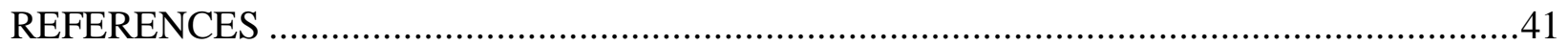

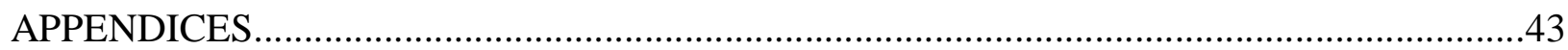

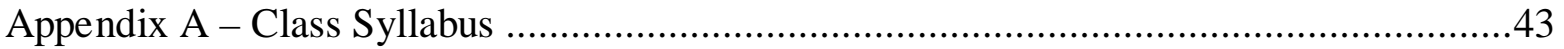

Appendix B - Project Rubric............................................................................46

Appendix C - Assignment List ..................................................................47

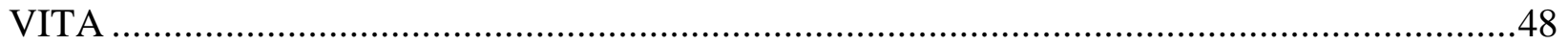




\section{LIST OF TABLES}

Table Page

1 - Legend of NC State Community College Class Types .................................................10

2 - Breakdown of BRCC Classes Taught in the Past 5 Years .................................................11

3 - Breakdown of NCCCS Classes Taught in the Past 5 Years..............................................11

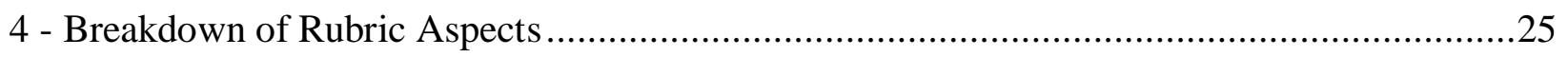

5- Rubric Scale Breakdown.....................................................................................26

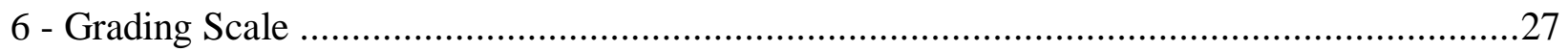

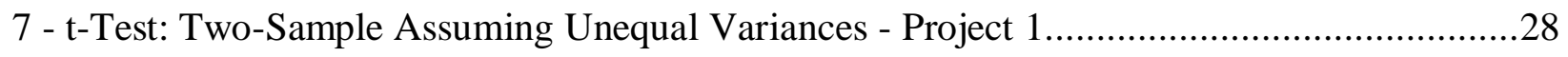

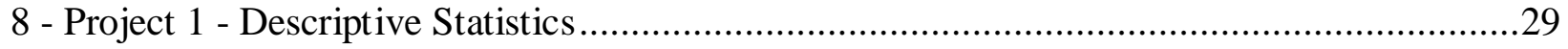

9 - t-Test: Two-Sample Assuming Unequal Variances - Project 2......................................31

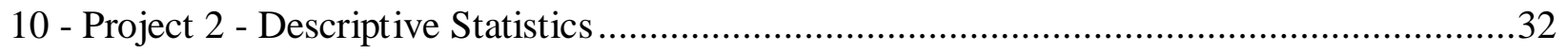

11 - t-Test: Two-Sample Assuming Unequal Variances - Project 3......................................34

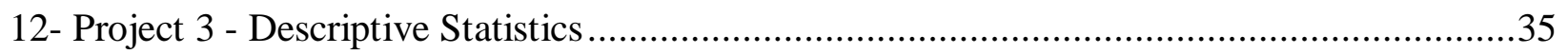




\section{LIST OF FIGURES}

Figure $\quad$ Page

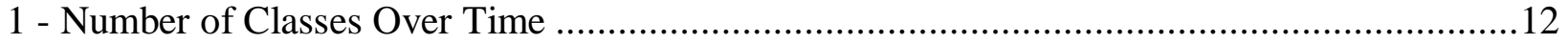

2- Project 1 Tutorial Example............................................................................................22

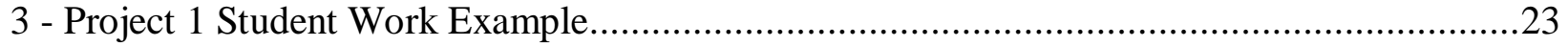

4 - Project 2 Student Work Example......................................................................23

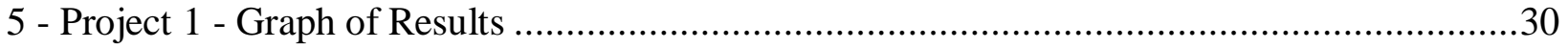

6 - Project 2 - Graph of Results ...................................................................................32

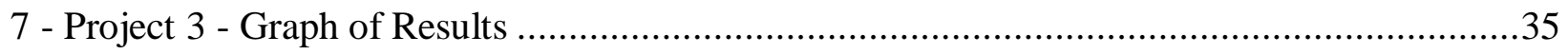

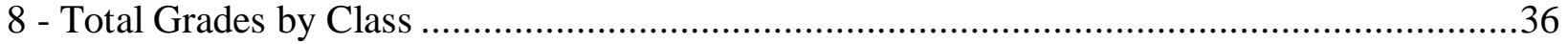




\section{CHAPTER 1}

\section{INTRODUCTION}

With increasing concern over the state of the education system in the United States, more and more emphasis is being placed on teaching methods. As internet related infrastructure becomes cheaper and more powerful, online learning environments are taking a stronger presence in most higher education institutions, and video content is being sought for these environments. However, the effectiveness of using video as a teaching tool is still uncertain. Without additional research, video remains an expensive and unproven gamble within an already struggling system.

Like all new technologies, video was expensive when first introduced. Teams of highly trained professionals were required to produce even the shortest video content. These high costs spurred some early research into the effectiveness of video as an educational tool. Ultimately, the

research found that despite the promise it showed, it was simply too expensive to be practical for teachers or even entire schools. Video then mostly fell by the wayside until recent advances in computers and the internet have brought the question of video as an educational tool to the forefront once again (Houston, 2000).

The purpose of this study is to evaluate the impact on student learning outcomes of video content as a primary teaching method compared to more traditional lecture based classes. When used as a primary teaching strategy, high quality, timely, on topic video can positively impact student learning. Even though this study focuses on the use of video at the college level, it is important to educators at all levels as it is examining and evaluating the usefulness of video as an educational tool. As a result of this study, educators from a wide variety of backgrounds can look at incorporating video into their classes as a way to reach greater numbers of students. 


\section{CHAPTER 2}

\section{SIGNIFICANCE}

Tough economic times result in a massive influx of students for community colleges. Whether from outsourced jobs or simple lay-offs, these displaced workers flock back to school looking to obtain new skills and become more competitive in a difficult job market. As the purpose of the community college in North Carolina is to serve the community, it is within the best interests of the college to get these workers retrained and back to work as fast as possible. Several obstacles exist when dealing with nontraditional students. Issues such as fear of going back to school after as many as 30 years, the need for part-time employment, and children in the household can make it difficult for displaced workers to enroll and/or complete degree programs. In order to accommodate many students who have other commitments as well as more traditional students looking for greater flexibility, community colleges are turning more to nontraditional distance learning class formats to accommodate student needs.

The state of North Carolina has several distance learning options. According to the North Carolina Community College System (NCCCS) Virtual Learning Community (2011), “Distance learning occurs when the interaction of a student and instructor is separated by place and/or time”. (http://vlc.nccommunitycolleges.edu/students/index.html) The various distance learning class formats available in the state of North Carolina are as follows:

- Hybrid Courses are those whose primary delivery is online with a requirement that students also meet in traditional face-to-face sessions as determined appropriate by the college. 
- Web-Supported Courses are those for which the primary delivery is via traditional faceto-face sessions with a requirement that those students have Internet access as a supplemental part of the course.

- Internet Courses are those for which $100 \%$ of the instruction is delivered through the Internet.

- Information Highway Courses are those for which $100 \%$ of the instruction is delivered by interactive video.

- Telecourses are courses in which video or television delivers $100 \%$ of the instruction.

- Teleweb Courses are those in which $100 \%$ of the primary delivery of instruction is via telecourse and also requires Internet accesses as a supplemental part of the course.

- Digital Media Courses are a course in which100\% of the instruction is delivered by nontelecourse digital video or media resources.

In addition to the distance learning classes, there are traditional classes, ITV or television-based classes, independent study, and cooperative education. This study looks only at hybrid and traditional classes; several of the other divisions have been grouped together into a category called "other". The Distance Learning Web Supported or Web-Assisted category is for the purposes of this study the same as Distance Learning Hybrid, on-line and face-to-face; however, these categories have not been combined because Blue Ridge Community College has only offered 14 Distance Learning Web Supported or Web-Assisted classes over the past 5 years (Table 1). 
Table 1 -

Legend of NC State Community College Class Types

\begin{tabular}{|l|c|}
\hline Distance Learning Hybrid, on-line and face to face & HY \\
\hline Distance Learning Internet Course & IN \\
\hline Traditional Courses & WB \\
\hline Distance Learning Web Supported or Web-Assisted & \\
\hline Grouped in graphs as "Other" & IS \\
\hline Independent Study & TV \\
\hline Distance Learning Telecourse & $\mathrm{TW}$ \\
\hline Distance Learning TeleWebcourse & $\mathrm{IH}$ \\
\hline Distance Learning Two-way Video Course & $\mathrm{DL}$ \\
\hline Other Distance Learning Course & $\mathrm{CP}$ \\
\hline Cooperative Education Co-op & $\mathrm{DM}$ \\
\hline Distance Learning Digital media & \\
\hline
\end{tabular}

The North Carolina Community College System Data Warehouse

(http://www.ncccs.cc.nc.us/training/datawarehousetraining/data_warehouse.html) supplied the data in Tables 2 and 3 as well as Figure 1. "The North Carolina Community College System data warehouse has been developed to give college and system office personnel access to statelevel information. This information includes student enrollments, faculty and staff employment, and course offerings." (The State of North Carolina, n.d.) 
Table 2 -

Breakdown of BRCC Classes Taught in the Past 5 Years

\begin{tabular}{|r|r|r|r|r|r|}
\hline & \multicolumn{1}{|l|}{ HY } & \multicolumn{1}{l|}{ IN } & \multicolumn{1}{l|}{ TR } & 274 \\
\hline $2005-2006$ & 435 & 1,120 & 0 & 10,078 & 270 \\
\hline $2006-2007$ & 590 & 1,346 & 7 & 9,018 & 296 \\
\hline $2008-2009$ & 1,097 & 1,890 & 0 & 8,306 & 563 \\
\hline $2009-2010$ & 1,842 & 2,242 & 0 & 9,121 & 451 \\
\hline Total & 4,896 & 8,149 & 0 & 10,670 & 1,854 \\
\hline
\end{tabular}

Table 3 -

Breakdown of NCCCS Classes Taught in the Past 5 Years

\begin{tabular}{|l|r|r|r|r|r|}
\hline & HY & \multicolumn{1}{l|}{ IN } & WB & TR & Other \\
\hline $2005-2006$ & 23,686 & 133,758 & 83,968 & 890,307 & 25,842 \\
\hline $2006-2007$ & 38,283 & 163,319 & 109,251 & 840,649 & 25,069 \\
\hline $2007-2008$ & 57,095 & 200,562 & 88,793 & 855,763 & 24,820 \\
\hline $2008-2009$ & 79,620 & 261,260 & 153,770 & 828,580 & 22,705 \\
\hline $2009-2010$ & 120,448 & 324,394 & 193,358 & 891,185 & 21,241 \\
\hline Total & 319,132 & $1,083,293$ & 629,140 & $4,306,484$ & 119,677 \\
\hline
\end{tabular}

While traditional classes still hold a clear majority over nontraditional classes, the prevalence of nontraditional classes is increasing. Blue Ridge Community College showed a 323\% increase in Hybrid and a 100\% increase in Internet based classes from 2005/2006 to 2009/2010. The state of North Carolina showed a greater increase of $408 \%$ for hybrid and $142 \%$ for internet based classes. The percent of Hybrid classes taught at Blue Ridge Community College has risen from 3.65\% in 2005/2006 to over 12\% in 2009/2010 while internet 
based classes have risen from $9.41 \%$ to almost $15 \%$ of total classes. While at the state level, hybrid classes grew from $2 \%$ to almost $8 \%$ and internet based from $11 \%$ to $21 \%$ of all classes taught.

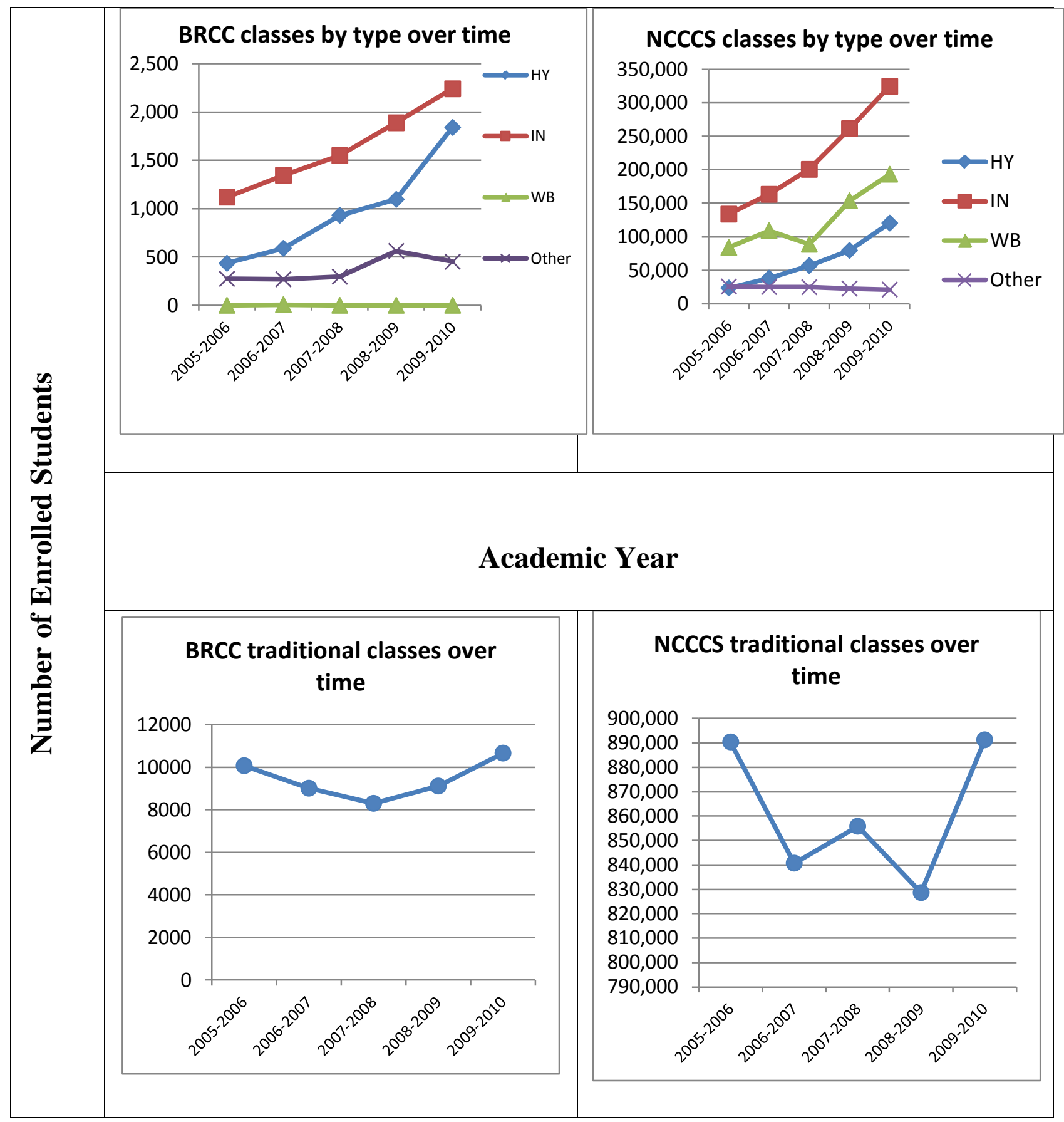

Figure 1 - Number of Classes Over Time 
These trends show no sign of slowing down. Even in years where overall classes are down, the overall number of hybrid and internet based classes are going up. As technology gets less expensive and more available, these nontraditional classes will continue to grow. Many institutions from Ivy League to local community colleges like Blue Ridge Community College have started using technologies such as iTunesU and Second Life. These tools further enhance the nontraditional experience, allowing students to easily access course material, video, audio, lectures, and examples as well as increasing the appeal of nontraditional classes.

This dramatic increase in both hybrid and internet based classes and the resulting effect on student learning outcomes in higher education institutions in North Carolina and the United States, make this study necessary to ascertain the impact and effectiveness of video as an educational tool. 


\section{CHAPTER 3}

\section{LITERATURE REVIEW}

Very little research has been done recently on video as an educational tool. A large portion of the research done is outdated and no longer completely accurate. Research done in the 1950s through the 1980s describes video as an expensive new technology that was rarely used in the classroom and not practical for classroom use. At that time producing a video required an expensive camera, as well as the skills to use it. A set with proper and specialized lighting had to be built or obtained just to shoot the video. The video then had to be taken to a specialized studio to be edited and converted to a usable format. This process required a lot of specialized equipment and well trained people to operate it. These requirements were often well out of most teachers’ budgets and expertise.

Not until 1986 did a study by Cottingham find that the use of video in the college classroom was gradually increasing. Cottingham (1986) surveyed seven small community colleges with 2,500 or fewer full-time students; all reported heavy and increasing use of video in classroom instruction. It is worth noting that Smeltszer (1988) reported a slight positive correlation between a student-centered approach to teaching and video use. These observations were never followed up on because in the 1990s research fell off sharply as educational researchers moved on to study computers.

Researchers abandoned the idea of video quickly in the 1990s. As the cost of technology fell and the capabilities of that technology increased, people started to find they could create educational video using their own computers. Video was no longer as expensive and unavailable as it once was (Houston, 2000). The rise of the personal computer and the internet gave teachers the ability to create and edit production quality video without leaving their offices. Small 
cameras became available for less than $\$ 100$, allowing teachers to record lectures. Software programs like TechSmith’s Camtasia Studio $\odot$ allowed teachers to record the output from their monitors as well as edit the video and add sound and other visual effects. These tools gave the teachers the ability to revisit video as an educational tool. Today, video is once again taking a strong position in the classroom but lacks the research to properly justify its continued use and funding.

Other studies like Children and Television: Video-Based Learning by Very Young Children show that at a young age our brains are able, "to perceive and interpret (within their cognitive level) video images”. (p. 1) In Schmitt and Anderson's (2002) study Television and Reality: Toddlers ' Use of Visual Information from Video to Guide Behavior they were able to show that at 30 months, a child is able to apply information garnered from video and apply it to real world scenarios. These studies provide not only a precedent but a background supporting this study, showing that even at a remarkably young age, video is being successfully used as an educational tool.

Evans and Foster (1997) looked at the idea of self learning using video. Their study, as well as others like it, focused on students using video and not having a classroom interaction. The studies showed that many of these students reached out to each other in informal sessions to facilitate learning (Littlefield, 1994; Mullins \& Mullins, 1994). Copley (2007) in Audio and video podcasts of lectures for campus-based students: production and evaluation of student use reported the majorty of students using downloadable course lecture podcasts did so as an additional study aid. These studies are important because they show that video alone is not enough to facilitate efficient learning. Video instead needs to supplement other course work and learning tools to provide the student an opportunity to learn. 
Evans (1995) also found that the students using video reported they felt like they had a stronger grasp of the theory than did the traditional students. Evans and Foster (1997) found that videos fostered greater self-reliance in the students. More advanced students seemed to accept the videos easier and reported fewer repeated viewings of the videos. (Evans \& Foster, 1997). This is more meaningful than a first glance suggests. With greater emphasis in the United States being placed on lifelong learning and adult learning programs, having an educational tool that also increases self-reliance in students is a huge advantage for students and teachers.

Complaints concerning the use of video as a teaching tool mentioned in the research were addressable aspects such as the speaker talking too fast or referencing things the students had never heard of. This can be easily corrected in the next iteration of the video by speaking slower and putting more current examples into the video. Evans and Foster (1997) also noted that the biggest limitation in the study was student motivation. Every class is plagued by unmotivated students. Some students simply do not want to put forth the effort to master the material. Video excels, however, in its ability to allow motivated students to excel while not being held back by the unmotivated ones.

Martin, Evans, and Foster (1995) found that video when combined with workbooks and a computer package resulted in considerable satisfaction from students. Emphasis in this article was placed on the student's self-learning and the overall experience. Martin et al. (1995) found they gained more time to work with the students as well on consultation. They also reported the overall level of critical and reflective learning increased in test subjects as well as a reduction in formal student to staff time. The majority of complaints regarding videos from these studies in general are aspects that can easily be changed as well. 
Demetriadis and Pombortsis (2007) found that the major disadvantage to E-lectures was the lack of immediate communication between teachers and students. Using video inside of the online hybrid classroom increased opportunities for student-teacher interaction while minimizing most of the limitations reported within the literature.

Schwan and Riempp (2004) and Zhang, Zhou, Briggs, and Nunamaker (2006) found that having an interactive element to the video (i.e. stop, pause, play, and rewind) decreased the time necessary for learning as learners could review important or poorly understood material, facilitating knowledge acquisition. Thankfully, most computer based media players today have these functions built in. These studies also showed the students reported higher satisfaction overall when using the video with interactive controls.

Understanding and being able to apply the material requires more than simply memorizing vocabulary or knowing a few facts. To truly understand presented material, the student has to be able to internalize it on a deeper lever. "Active learning recognizes that individuals have to engage with the content and with others, unveil prior ideas, make connections between ideas, and construct new knowledge from their experiences” (Ueckert \& Gess-Newsome, 2008, p. 48). Active learning techniques require students to go beyond a simple "follow the steps assignment" to apply the material to a real world problem. This is a vital skill for students in rapidly changing fields like technology.

Evans and Foster (1997) also mention that they were unable to accurately measure the role of the videos as a catalyst for learning. This research will help to fill the knowledge gap by measuring the effect of using video as a teaching tool in a North Carolina Community College system classroom. Although a number of media usage studies have been conducted over the years, their scope often has been very broad, attempting to document all technologies used by 
college faculty members. In contrast, this study focuses specifically on the use of video for the purpose of presenting and demonstrating new skills and techniques as well as supplementing course content.

Research Question

Do video tutorials significantly impact student learning outcomes when used as a primary teaching method in the community college hybrid based classroom?

Hypotheses

H1: Video tutorials will make a statistically significant positive impact on student learning outcomes when used as a primary teaching method in the community college hybrid based classroom.

H2: Students using video tutorials will have higher grades compared to students using written tutorials. 


\section{CHAPTER 4}

\section{METHODS}

\section{Sampling}

North Carolina (NC) Community Colleges have an open enrollment policy. Students are permitted to enroll for any class assuming they meet the prerequisite requirements for college classes. Using the open enrollment policy of the college, classes are composed of a wide range of students with an interest in Simulation and Game Development. These students were community college students between 18 and 40 years of age enrolled in a technology driven program. Of the 19 participants, three were removed from the study due to a failure to complete any of the three assignments. Fifteen of the remaining students were male and 1 was female. The combined make-up of the classes was heavily skewed to the male gender $(M=15)$ and the 18 -23 age group. Both the control and experimental group contained eight subjects assigned to either group based on registration date.

\section{Experimental Setting}

This study draws on the Simulation and Game Development (SGD) program at Blue Ridge Community College, using SGD 114 - 3D Modeling I (See Appendix A for class syllabus). SGD 114 - 3D Modeling I is only offered as a spring semester class. The control group took place in spring semester of 2010, while the experimental group took place in spring semester of 2011. In each case, the final grade from the rubric was collected from each of three projects spanning the course of the entire semester. The data were evaluated to determine the growth in the students' overall ability to use the tools presented in class into a successful project. 


\section{Operationalizations}

\section{Definitions}

- Online hybrid classroom - A traditional classroom setting that also uses a virtual learning environment (for the purpose of this study - Moodle - www.moodle.org) to assist in the educational experience.

- Video - Video tutorials from numerous sources were reviewed, and final selections were available for free from both 3D Buzz (www.3dbuzz.com) or purchased from The Gnomon Workshop (http://www.thegnomonworkshop.com/). All video tutorials were created using Autodesk Maya $\bigodot$ software in addition to Adobe Photoshop`. All video tutorials in this study were available for students to take home and view on their personal computers as well as in the lab.

- Performance - For this study student performance describes the student ability as demonstrated by the three selected projects to master the student learning outcomes stated for each project.

- Dependent Variable - The final grade of each project.

- Independent Variable - The delivery method of primary instruction.

\section{Interventions}

- Video shown in class was educational in nature and contained content of an appropriate nature.

- Videos shown in class were presented in English. 
SGD 114 - 3D Modeling I used Autodesk Maya $($ software in addition to Adobe Photoshop`. The class was project driven, with a modeling assignment due every week on Sunday. Students were expected to watch or read through the tutorial as presented. It was suggested to both groups to work the tutorial exactly as it appeared in the tutorial for practice before starting their own model. Students were then expected to work through the tutorial using it as a sample a second time and then producing their own unique model using the tools and techniques presented in the tutorial.

Active learning techniques were practiced by assigning the student a creative project based on the tutorial. Students had to make a real world connection between the concepts in the tutorial and the real issues that arose with a project.

Both classes met twice a week for a 16-week semester. On the first class of the week, the instructor would review or show the first part of the tutorial. The tutorials were often longer than the class period, so only the first part of the tutorial would be presented. Students were given either access to an online portable document format (.pdf) file to download or all of the tutorial videos to take home with them. The second class was reserved for class critique of classmates' work and for personalized assistance and questions. Students were given the remainder of the second class of the week as lab time to work on their projects and ask questions of each other and the instructor.

\section{The Control Group}

Assignments in the control class $(n=8)$ consisted of a series of written tutorials. These tutorials came from the tutorials included in the Autodesk Maya $\subset$ help file as well from Learning Autodesk Maya 2008, (Official Autodesk Training Guide, ISBN 1897177429). Each 
tutorial consisted of step-by-step written instructions to set up and complete a project. The tutorials also contained additional explanation on tool use and settings. Students were given the written tutorial to review. Suggested workflow for the week was for the student to work each step of the written tutorial as presented until the project was completed. After finishing the tutorial as presented, the student was then to start on the assignment.

\section{The Experimental Group}

The experimental group $(n=8)$ was taught in the same manner as the control group. Assignments in the experimental group consisted of a series of video tutorials, opposed to the control group's more traditional written tutorials. These video tutorials were prepared by The Gnomon Workshop (http://www.thegnomonworkshop.com/) as well as 3D Buzz (http://www.3dbuzz.com). The video tutorials also contained additional explanation on tool use and settings.

\section{Procedure}

Written tutorial learning objectives were documented and matched with the video project tutorials’ documented learning objectives (See Appendix C). Three projects were chosen. Project one was an introductory project. The tutorial walked through the creation of a high and low poly count version of a simple futuristic spacefighter helm. See Figure 2 for an example of the finished tutorial model and Figure 3 for an example of the finished student

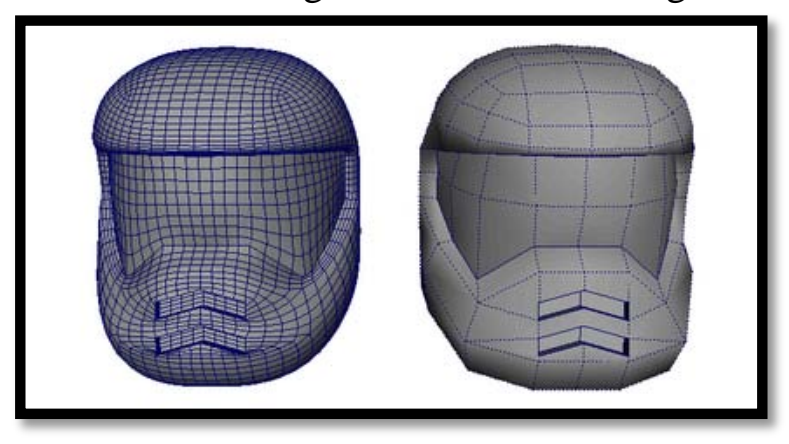

Figure 2- Project 1 Tutorial Example 
project. A strong recommendation was made to complete the tutorial as presented before starting on the assignment, a custom helmet of the student's design.

The students could create any type or style of helmet. They were required to find or create 2D reference images that could be imported into Autodesk Maya as image planes. Create Faces, Combine, Bridge, and Smooth tools had to be used as well. This project, presented at the beginning of the semester, served to establish a baseline for measuring student

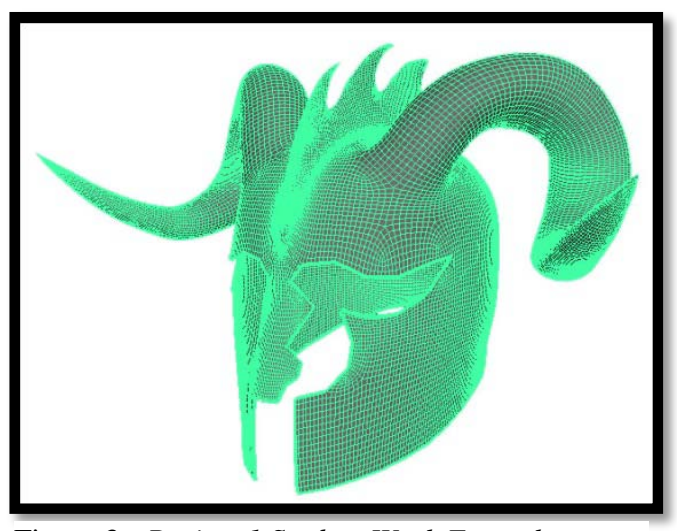

Figure 3 - Project 1 Student Work Example growth. Applicable student learning objectives for this project can be viewed in Appendix C Assignment List. Even though this represented a beginner project, it was graded using the same standards as the final project.

The second project took place in the middle of the semester. This project consisted of a

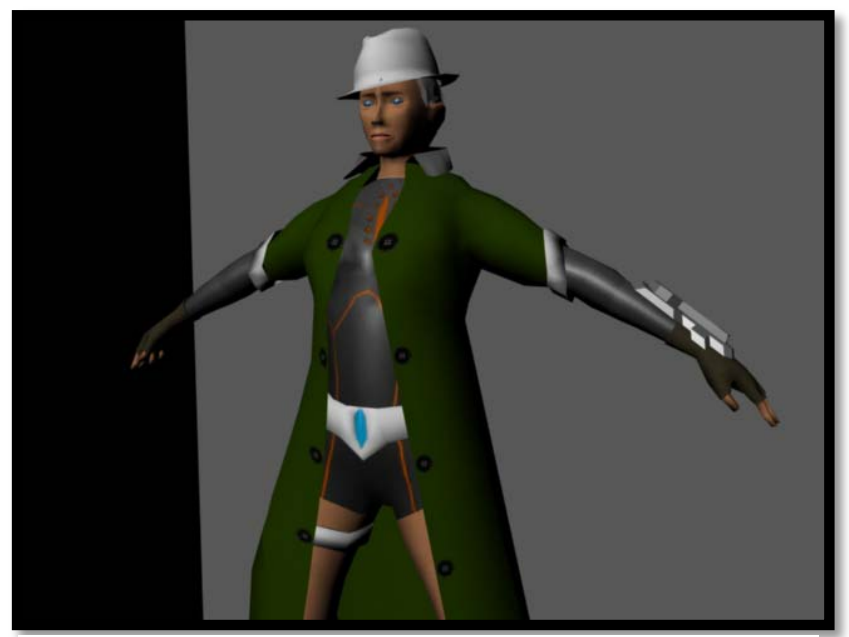

biped character. See Figure 4 for an

example of the finished student model.

Once again, a strong recommendation was

made to complete the tutorial as presented

before starting on the assignment, a custom

biped of the student's design. The student

Figure 4 - Project 2 Student Work Example

could create any type or style. Students did have to create or obtain their own reference images

for this project. The images provided from the tutorial were not accepted. Students were also required to show a basic understanding of biped design including naturally occurring edge loops. 
The Mirror Geometry, Merge and Merge to Center tools were also required skills. In addition the student was expected to apply tools from the previous project where applicable. Serving as midterm exam for the students, this comprehensive project provided a midterm sampling of student growth. Even though this represented a more advanced project then Project 1, it was graded using the same standards as the final project.

The final project for both groups was a comprehensive project to be chosen by the student. Students did have to create or obtain their own reference images for this project. Previously supplied reference material was not accepted in this assignment; the student was required to work with minimal guidance from the instructor. As problems arose, students were required to find creative solutions to their problems through research and work around techniques. In addition the student was expected to apply tools from the previous projects where applicable. This project represented the most advanced assignment of the semester as it depended $100 \%$ on the student with no tutorial to accompany it or additional direction. As a comprehensive final, this project showcased the student's ability to apply knowledge learned throughout the semester without step by step assistance from a written or video tutorial. Projects 1 and 2 were graded to the same standards expected for this project.

These projects spanned the length of the semester and were chosen to showcase the student's overall growth and represent a cross section of the total projects for the class. Each class consisted of at least 10 projects each covering the same material. All projects in each class were taught according to the prescribed methods described above.

Projects were graded according to a rubric (See Appendix B). The rubric was developed by Richard Sykes as a preliminary instrument to test how it could help later on in developing a tool for the measurement of 3D modeling. The rubric showed how the student applied the skills 
highlighted in each tutorial according to the six listed aspects. Each aspect of the project was rated according to the rubric. The rubric measured the student's work on six aspects. Each aspect of the rubric was chosen to assist student growth. By breaking down the project by these aspects, the students could see the specific areas in which they were excelling and the areas that still needed work. Table 4 shows the six aspects measured by the rubric.

Table 4 -

Breakdown of Rubric Aspects

\begin{tabular}{|c|l|}
\hline \multicolumn{1}{|c|}{ Skill } & \multicolumn{1}{c|}{ Example } \\
\hline $\begin{array}{c}\text { Content, Composition, } \\
\text { and Design }\end{array}$ & $\begin{array}{l}\text { Can the student create an overall composition? } \\
\text { Do design elements of the project make sense together? } \\
\text { Is the project's content appropriate for the assignment? }\end{array}$ \\
\hline Technical Requirements & $\begin{array}{l}\text { Is the project properly set up? } \\
\text { Is each object named appropriately? } \\
\text { Does the project meet any additional technical } \\
\text { requirements? }\end{array}$ \\
\hline Mechanics & $\begin{array}{l}\text { Is the project free from technical errors? } \\
\text { Are there any instances of clipping? } \\
\text { Is the model well constructed? }\end{array}$ \\
\hline Aesthetics & $\begin{array}{l}\text { Does the project look correct? } \\
\text { Are the proportions correct? } \\
\text { Are textures appropriate for the object? }\end{array}$ \\
\hline Storyboard/ & $\begin{array}{l}\text { Did the student make use of storyboards or reference } \\
\text { materials? } \\
\text { Deference Image } \\
\text { Daterials? }\end{array}$ \\
\hline Growth and & Did the student incorporate skills from previous projects? \\
\hline Progress & \\
\hline
\end{tabular}

The Growth and Progress aspect of the rubric showed students if they successfully incorporated the cumulative skills presented through the semester. The Growth and Progress aspect of the rubric was chosen as it was important for students to realize that there was often more than one way to accomplish a goal in modeling and that they needed to use all the tools available to them to be successful. 
The Storyboard/Reference Image aspect was chosen to gauge and develop the student's ability to produce work from an image. Most applications that use 3D modeling technology make extensive use of large teams. Students must be able to produce work to accurately portray work from other team members. The aesthetics aspect of the rubric showed that the student had an awareness that each project had a visual element, and that to be successful, the project had to be visually interesting to the end viewer.

Mechanics described the in-program technical aspects related to the model; whereas, technical aspects related to the project or file were covered in the Technical Requirements aspect. For example, a file that was misnamed would have points deducted from the Technical Requirements section. Once the student's file was opened inside Autodesk Maya $\odot$, a naming error on the model would count against the Mechanics section. Again this was important due to the basic 3D process and ensuring that other team members could work on the student's file.

The Content, Composition, and Design section measured the project holistically. This aspect measured the student's overall ability to put together a complete and total project based on the project learning objectives. The rubric scale breaks down as shown in Table 5;

Table 5-

Rubric Scale Breakdown

\begin{tabular}{|l|l|l|l|l|}
\hline $\begin{array}{l}\text { Skill Level } \\
\text { Shown }\end{array}$ & Failure & Novice & Intermediate & Mastery \\
\hline Points Awarded & $0-2$ & 3-5 & $6-8$ & $9-10$ \\
\hline Description & $\begin{array}{l}\text { The student has } \\
\text { failed to } \\
\text { successfully } \\
\text { complete the } \\
\text { listed aspect }\end{array}$ & $\begin{array}{l}\text { The student had } \\
\text { an elementary } \\
\text { grasp of the } \\
\text { aspect, but still } \\
\text { needs } \\
\text { improvement }\end{array}$ & $\begin{array}{l}\text { The student has } \\
\text { an adequate } \\
\text { grasp of the } \\
\text { aspect. }\end{array}$ & $\begin{array}{l}\text { The student has } \\
\text { mastered the } \\
\text { aspect. }\end{array}$ \\
\hline
\end{tabular}


Each aspect of the rubric measures a different aspect of the project and was weighted. Points were awarded based on the 10 point scale detailed above, and then multiplied by the aspect's weight. Weighted totals were then added to determine the project's total grade. A letter grade was then assigned using the following grading scale outlined in Table 6, as per Blue Ridge Community College's policy.

Table 6 -
Grading Scale
\begin{tabular}{|c|c|}
\hline Letter Grade & Range \\
\hline A & $100-93$ \\
\hline B & $92-85$ \\
\hline C & $84-77$ \\
\hline D & $76-70$ \\
\hline F & $<69$ \\
\hline
\end{tabular}

Final aggregate grades for each project were compared using graphs, charts, and measures of central tendency.

\section{Analysis - Project 1}

The two low grades in the experimental group should be given minimal credence, as those represent unfinished projects, whereas all the other projects in the study were completed projects. The projects were not excluded from the study because the students did complete the rest of the assignments in the study. These two projects were treated as outliers for the purposes of this study. Due to the nature of those two projects, a second set of statistics have been prepared to accurately represent the results. 
A two tailed t-test was run to determine if experimental and control groups were statistically different. The t-test was chosen due to the small sample size of eight associated with the study. With the only difference between the groups in the test being the teaching method, the results of the t-test are viable. The t-test: Two-Sample Assuming Unequal Variances function was run in Microsoft Excel 2007, with an alpha value of .05. The two tail test was run to see the effect on one group to be less or more effective than the other group. The two tail t-test results shown in Table 7 show that there is a statistical difference between the two groups.

Table 7-

t-Test: Two-Sample Assuming Unequal Variances - Project 1

\begin{tabular}{|l|r|r|}
\hline t-Test: Two-Sample Assuming Unequal Variances - Project 1 \\
\hline & Control Group & $\begin{array}{c}\text { Experimental } \\
\text { Group }\end{array}$ \\
\hline Mean & 59.37 & 67.37 \\
\hline Variance & 338.83 & 892.55 \\
\hline Observations & 8 & 8 \\
\hline $\begin{array}{l}\text { Hypothesized Mean } \\
\text { Difference }\end{array}$ & 0 & \\
\hline df & 12 & \\
\hline t Stat & -0.64 & \\
\hline P(T<=t) one-tail & 0.26 & \\
\hline$t$ Critical one-tail & 1.78 & \\
\hline$P(T<=t)$ two-tail & 0.53 & \\
\hline$t$ Critical two-tail & 2.17 & \\
\hline
\end{tabular}

As seen below, (Table 8) the mean for the experimental group was 67.37 or 83.16 for the modified experimental group, 8 and 23.78 respectively points higher than the control group’s mean of 59.37. Using the modified experimental group, the lowest grade of 70 was well above the mean and only 10 points away from the highest grade in the control group. The modified experimental group grades were also more tightly grouped, 70 to 90 or a total range of only 20 
points. The standard deviation for the control group 18.40 was more than double the standard deviation for the modified experimental group of 7.25. This reduced range of values showed that on average more students were able to glean more information from the video. It also shows that the entire class as a whole was able to perform at a higher level as well. Median grades were a full 22 points higher than the control group in the modified experimental group and 20 points with the two outliers figured in.

Even with the two outlier projects considered, the experimental group performed substantially better then the control group. The projects submitted by the students exposed to the video tutorials had at the end of this project a higher overall ability to use the tools presented in class to create a successful project.

Table 8 -

Project 1 - Descriptive Statistics

\begin{tabular}{|l|r|l|r|l|r|}
\hline \multicolumn{2}{|c|}{ Control Group } & \multicolumn{2}{c|}{ Experimental Group } & $\begin{array}{c}\text { Modified Experimental Group } \\
\text { - Without Outliers }\end{array}$ \\
\hline Mean & 59.37 & Mean & 67.37 & Mean & 83.16 \\
\hline Median & 62.5 & Median & 82.5 & Median & 84.5 \\
\hline Standard Deviation & 18.40 & Standard Deviation & 29.87 & Standard Deviation & 7.25 \\
\hline Range & 40 & Range & 70 & Range & 20 \\
\hline Minimum & 40 & Minimum & 20 & Minimum & 70 \\
\hline Maximum & 80 & Maximum & 90 & Maximum & 90 \\
\hline Count & 8 & Count & 8 & Count & 6 \\
\hline
\end{tabular}




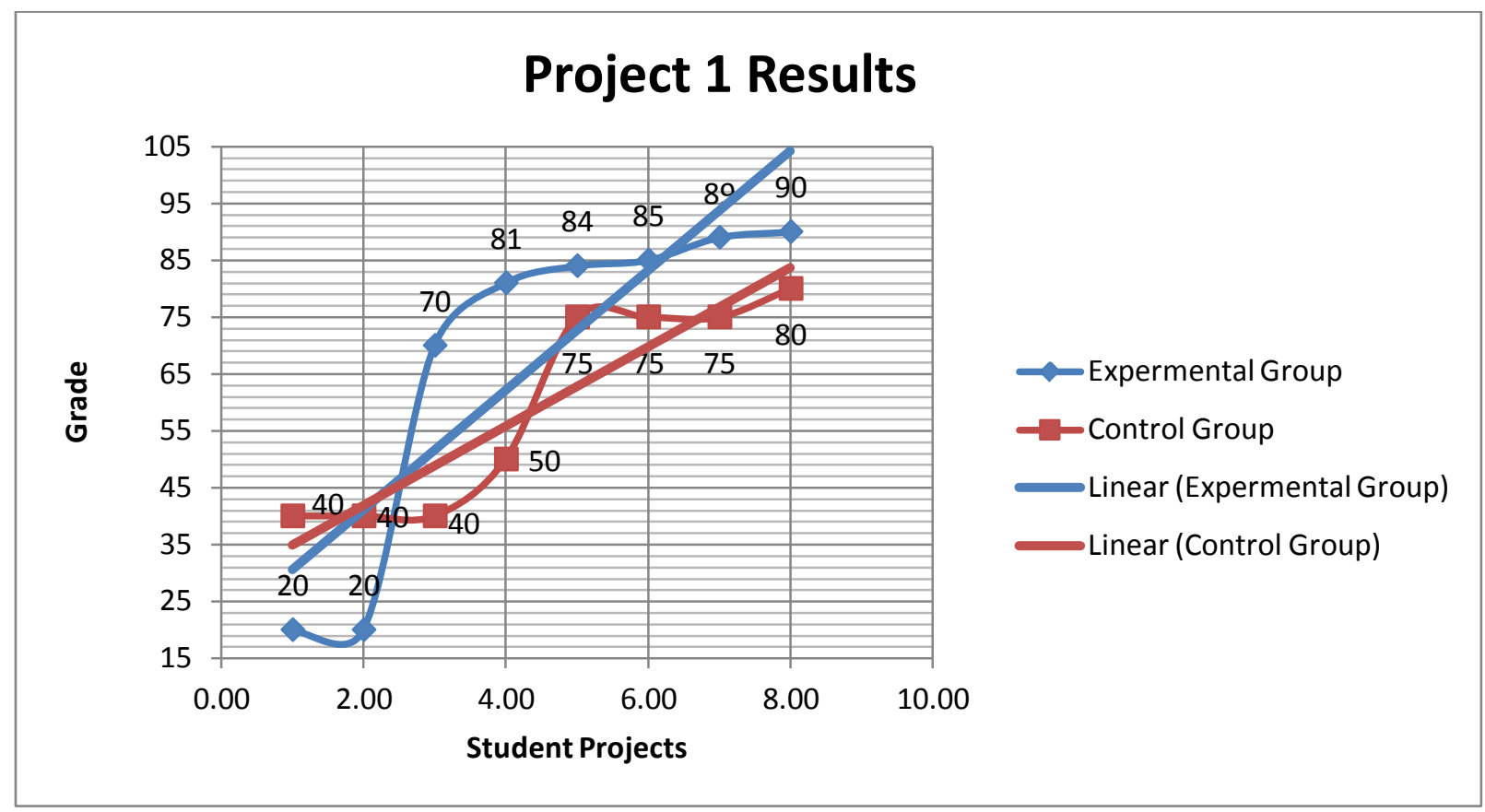

Figure 5 - Project 1 - Graph of Results

As is evident in Figure 5, with the exception of the two outliers, only one grade from the experimental group falls below the highest grade in the control group. The graph shows that the top five grades in the project were earned by students in the experimental video tutorial group. When excluding the noted outliers in the experimental group, the student with the lowest grade in the class still outperformed half of the students in the control group. This supports the results of the descriptive statistical analysis, suggesting the experimental group performed substantially better then the control group.

\section{Analysis - Project 2}

As seen in Table 10 and Figure 6, the mean for the experimental group was 14.75 points higher than the control group. All of the projects turned in for this project were complete; therefore, there were no outliers in this data set. The lowest experimental group grade of 80 was 
well above the 71.25 mean of the control group, an 8.75 point difference. On the grading scale used in the class , 71.25 equates to a "D" while an 80 equates to a "C" (See Table 6). Experimental group grades were once again also more tightly grouped, 80 to 90, a range of only 10 points. The standard deviation for the control group 15.29 more than triple the standard deviation for the experimental group of 5.01. This significantly reduced range of values showed that on average more students were able to glean more information from the video. It also shows that the entire class as a whole was able to perform at a higher level as well. Median grades were a full 14 points higher in the experimental group.

A two tailed t-test was run to determine if experimental and control groups were statistically different. The t-test was chosen due to the small sample size of eight associated with the study. With the only difference between the groups in the test being the teaching method, the results of the t-test are viable. The t-test: Two-Sample Assuming Unequal Variances function was run in Microsoft Excel 2007, with an alpha value of .05. The two tail test was run to see the effect on one group to be less or more effective than the other group. The two tail t-test results shown in Table 9 show that there is a statistical difference between the two groups.

Table 9 -

t-Test: Two-Sample Assuming Unequal Variances - Project 2

t-Test: Two-Sample Assuming Unequal Variances - Project 2

\begin{tabular}{|l|r|r|}
\hline & Control Group & Experimental Group \\
\hline Mean & 71.25 & 86 \\
\hline Variance & 233.92 & 25.14 \\
\hline Observations & 8 & 8 \\
\hline Hypothesized Mean Difference & 0 & \\
\hline$d f$ & 8 & \\
\hline$t$ Stat & -2.59 & \\
\hline$P(T<=t)$ one-tail & 0.016 & \\
\hline$t$ Critical one-tail & 1.85 & \\
\hline$P(T<=t)$ two-tail & 0.032 & \\
\hline$t$ Critical two-tail & 2.30 & \\
\hline
\end{tabular}


This project again showed the experimental group performed substantially better than the control group. The projects submitted by the students exposed to the video tutorials had at the end of this project a higher overall ability to use the tools presented in class to create a successful project.

Table 10 -

Project Two - Descriptive Statistics

\begin{tabular}{|l|r|l|r|}
\hline \multicolumn{1}{|c|}{ Control Group } & & Experimental Group & \\
\hline \hline Mean & 71.25 & Mean & 86 \\
\hline Median & 75 & Median & 89 \\
\hline Standard Deviation & 15.29 & Standard Deviation & 5.01 \\
\hline Range & 50 & Range & 10 \\
\hline Minimum & 40 & Minimum & 80 \\
\hline Maximum & 90 & Maximum & 90 \\
\hline Count & 8 & Count & 8 \\
\hline
\end{tabular}

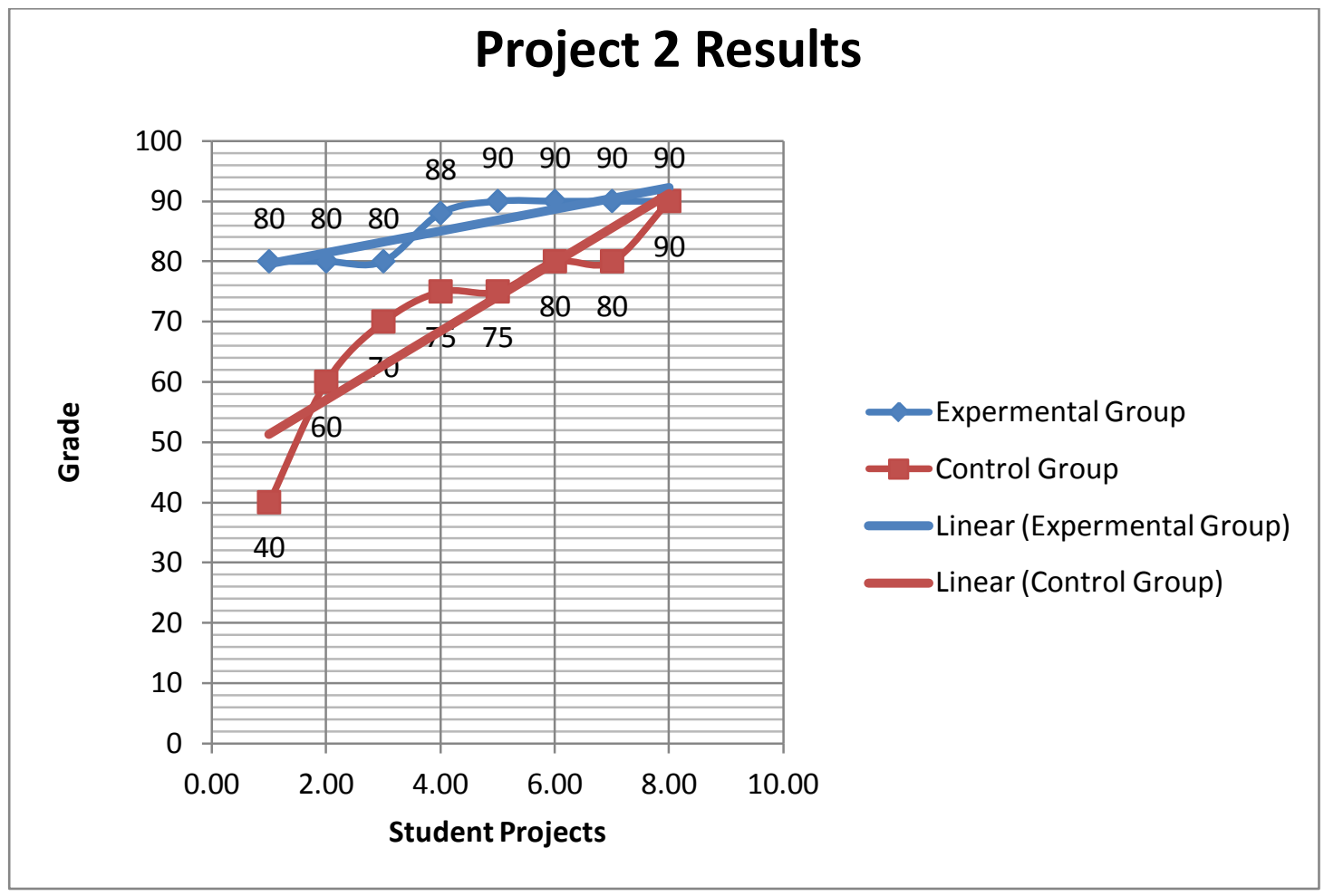

Figure 6 - Project 2 - Graph of Results 
As is evident in Figure 6, the lowest grades in the experimental group once again higher than over $50 \%$ of the grades in the control group. While one student in the control group earned a 90 on the project, the next highest grade in the control group equaled the lowest grade in the experimental group. This graph supports the results of the descriptive statistical analysis, suggesting the experimental group performed substantially better then the control group.

\section{Analysis - Project 3}

As seen in Table 12 and Figure 7, the mean for the experimental group was over 22 points higher than the mean of the control group. All of the projects turned in for this project were complete; therefore, there were no outliers in this data set. The lowest experimental group grade of 85 was well above the 65.63 mean of the control group, a 19.37 point difference. On the grading scale used in the class, 65.63 would round to 66 which in turn equates to an " $F$ " while an 85 equates to a "B" (See Table 6). Experimental group grades were once again also more tightly grouped, 85 to 100, a range of only 15 points. The standard deviation for the control group 27.95 was over 5 times that of the standard deviation for the modified experimental group of 5.17. This reduced range of values showed that on average more students were able to glean more information from the video. It also shows that the entire class as a whole was able to perform at a higher level as well. Median grades were a full 25 points higher in the experimental group.

A two tailed t-test was run to determine if experimental and control groups were statistically different. The t-test was chosen due to the small sample size of eight associated with the study. With the only difference between the groups in the test being the teaching 
method, the results of the t-test are viable. The t-test: Two-Sample Assuming Unequal Variances function was run in Microsoft Excel 2007 with an alpha value of .05. The two tail test was run to see the effect on one group to be less or more effective than the other group. The two tail t-test results (Table 11) show that there is a statistical difference between the two groups.

Table 11 -
t-Test: Two-Sample Assuming Unequal Variances - Project 3
\begin{tabular}{|l|r|r|}
\hline t-Test: Two-Sample Assuming Unequal Variances - Project 3 \\
\hline & Control Group & $\begin{array}{c}\text { Experimental } \\
\text { Group }\end{array}$ \\
\hline Mean & 65.62 & 91.25 \\
\hline Variance & 781.69 & 26.78 \\
\hline Observations & 8 & 8 \\
\hline Hypothesized Mean Difference & 0 & \\
\hline df & 7 & \\
\hline t Stat & -2.54 & \\
\hline $\mathrm{P}(\mathrm{T}<=\mathrm{t})$ one-tail & 0.019 & \\
\hline & & \\
$\mathrm{t}$ Critical one-tail & 1.89 & \\
\hline $\mathrm{P}(\mathrm{T}<=\mathrm{t})$ two-tail & 0.03 & \\
\hline $\mathrm{t}$ Critical two-tail & 2.36 & \\
\hline
\end{tabular}

This project showed, like the two before it, that the experimental group performed substantially better than the control group. The projects submitted by the students exposed to the video tutorials had at the end of this project a better overall quality and represented the students ability to use the tools presented in class to create a more successful project. 
Table 12 - Project 3 - Descriptive Statistics

\begin{tabular}{|l|r|l|r|}
\hline \multicolumn{1}{|c|}{ Control Group } & & Experimental Group & \\
\hline \hline Mean & 65.62 & Mean & 91.25 \\
\hline Median & 65 & Median & 90 \\
\hline Standard Deviation & 27.95 & Standard Deviation & 5.17 \\
\hline Range & 80 & Range & 15 \\
\hline Minimum & 20 & Minimum & 85 \\
\hline Maximum & 100 & Maximum & 100 \\
\hline Count & 8 & Count & 8 \\
\hline
\end{tabular}

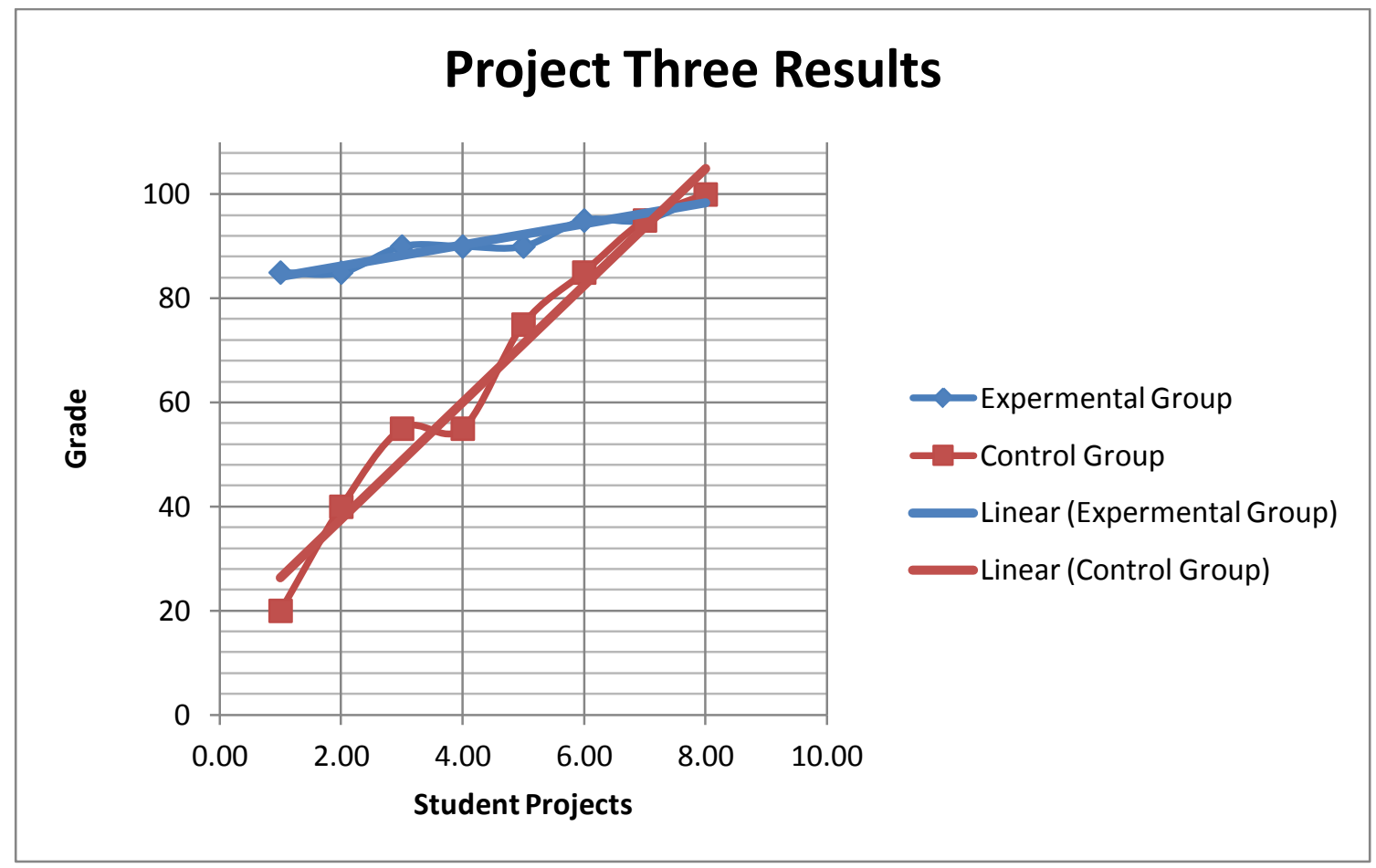

Figure 7 - Project 3 - Graph of Results 
Figure 7 shows that half of the control group performed worse than the lowest performer in the experimental group. The control group also contained the lowest grade of the semester, excluding the partially completed projects in project one already identified as outliers. This suggests that the experimental group was more successful in applying the course concepts to a project without step by step direction. In addition, this graph supports the results of the descriptive statistical analysis, suggesting that the experimental group performed substantially better then the control group.

The summarized grade information in Figure 8 suggests that the students in the control group had a harder time grasping the concepts presented. Nine out of 24 total projects failed to meet the standards of the final project it was graded against, and another 7 were of below average quality. The students in the experimental group, with the exception of the two outliers, managed to pass every project with 16 of 24 at an above average level.

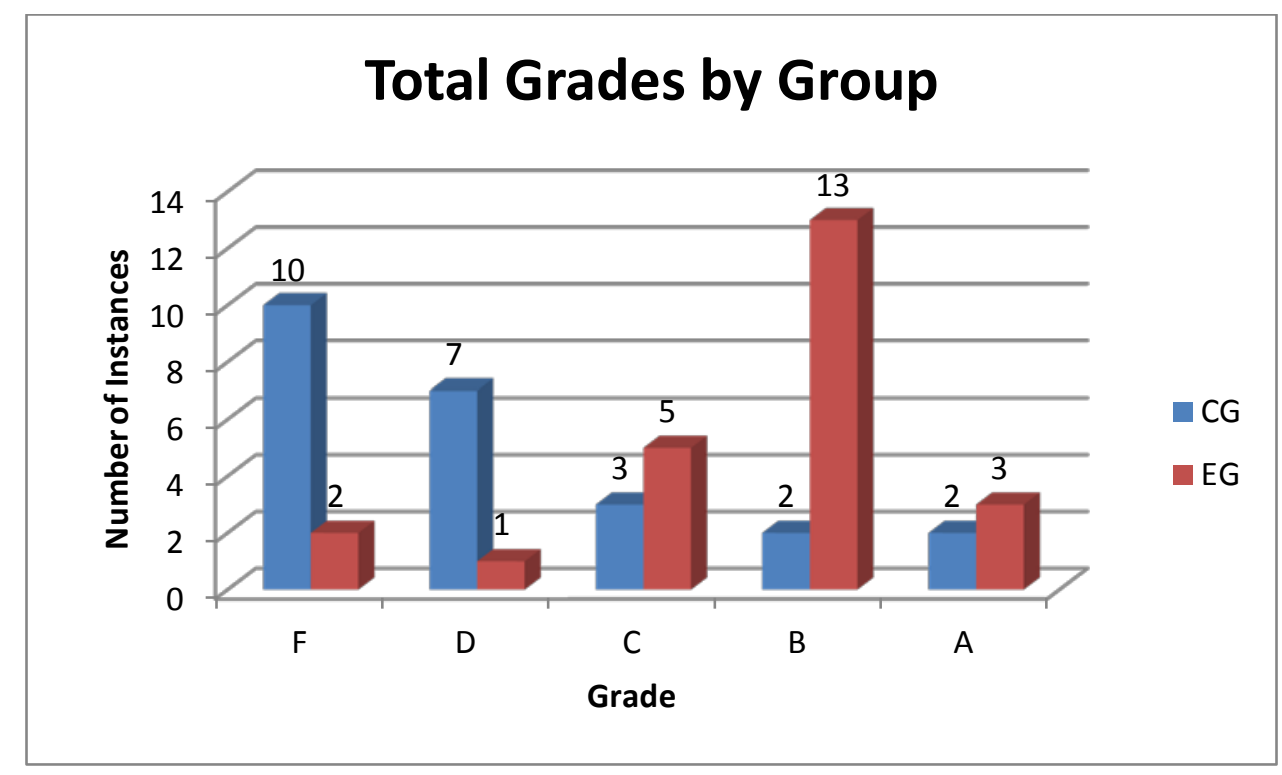

Figure 8 - Total Grades by Class 
The standard deviation for each of the experimental group projects was fairly steady, varying by only 2.24 points between all three projects. The standard deviation for each of the experimental groups however fluctuated by 13 points. This shows that the video tutorials were more successful and consistent in conveying the necessary information to the students. Both groups showed an increase in standard deviation in the final project. However, the experimental

group's increase was slight, only .16, whereas the control group had a huge increase of almost 13 points between the second and final projects. This suggests that the video tutorials allowed a greater number of students to gain a stronger grasp of the tools and concepts presented. As a result of this increased understanding, the video tutorials better prepared students to create the final project with no tutorial direction.

\section{Limitations}

There are a number of limitations inherent in this study.

1. Due to the nature of the selection process using small classes in a community college, sample sizes were small. Repeated studies are needed to increase sample size.

2. Even with a rubric in place, since only one instructor was responsible for grading projects, the possibility for bias exists. In future studies multiple instructors would need to grade each assignment according to the syllabus in order to limit potential bias.

3. Written tutorials were not transcripts of the video tutorials. Wording in the written tutorials may have been less clear then in the video. In future studies written tutorials will need to be transcripts of the video to ensure clarity. 
4. As a visually intense program, Simulation and Game Development may attract more visual learning centered students. In order to ensure the impact of video across all students, the study will need to be conducted across several subjects.

\section{Discussion}

The statistical analyses in this study was used to attempt to answer the research question "Does video significantly impact student learning outcomes when used as a primary teaching method in the community college hybrid based classroom?” The dependent variable of the study was the grade of each project, with the independent variable being the delivery method of primary instruction. A t-test was first run to determine if there was a statistical difference between the control and experimental group in each project. The impact of the independent variable on the dependent variable was then measured by comparing the final grades for each group’s projects using descriptive statistics. Descriptive statistics were used to summarize the data set and to present quantitative data in a manageable form. The t-tests and descriptive statistics were compiled using Microsoft Excel@ 2007. The impact of the independent variable on the dependent variable was then measured again in aggregate form using various charts and graphs. Once again the charts and graphs were compiled using Microsoft Excel@ 2007.

Descriptive statistics, charts, and graphs were used for the analysis as the aim of the study was to determine the impact on student work, and these methods provided the clearest and most accurate means of interpreting the data given the nature of the data and the sample size.

The descriptive statistics have shown that students in the experimental group statistically performed better then the control group. This affirms H1 by showing a statistically significant positive impact on student learning outcomes when Video was used as a primary teaching 
method in the community college hybrid based classroom. The secondary graphs and charts showed that the experimental group had higher grades than the control group. This affirms H2 by showing that students using video tutorials did have higher grades compared to students using written tutorials.

The hybrid classroom where students were meeting for face-to-face time complemented the informal sessions to facilitate learning described in Evans and Foster (1997) as well as other studies like it (Littlefield, 1994; Mullins \& Mullins, 1994). Considering Copley (2007), students were forced to do their own work and not just copy the tutorial. This provided the supplemental course work and learning tools Copley suggested to provide the student an opportunity to learn.

Evans (1995) found that the students using video in that study reported they felt like they had a stronger grasp of the theory than did the traditional students. The comprehensive final helps to support Evans's findings. When made to apply the skills learned from the videos, the students using video in the study performed better as a group then the nonvideo students.

This study also lends credence to Evans and Foster (1997) when they noted that the biggest limitation in their study was student motivation. While three students in the study were dropped from the class, and therefore the study due to simply not wanting to put forth the effort to master the material, the students in the experimental group, as evidenced by their grades, remained more motivated throughout the semester.

By calling for students to watch the video and then produce an original work based on that video, this study was able to incorporate the active learning techniques Ueckert and GessNewsome (2008) discussed. These assignments pushed past measuring the student's ability to simply follow directions or complete the listed steps. They measured, through the final product, the class's ability to engage the content and apply it in a real world problem. 
Overall, it was found that the experimental group outperformed the control group in this study. The students using the video tutorials were better able to use the tools and complete the stated student learning outcomes. These students were also better able to apply the concepts and techniques of the class to an unguided project of their own choosing. While more research is necessary, this study suggests the use of video significantly impacts student learning outcomes when used as a primary teaching method in the community college hybrid based classroom, and that by using video tutorials, students were able to better meet the requirements of the rubric and thereby earn higher grades.

However, while the experimental group as a whole outperformed the control group, both groups included "A" grades in the final project. This suggests that even though students seemed to grasp the concepts and techniques faster and easier from video, dedicated students can still produce quality projects with written instructions. 


\section{REFERENCES}

Anderson, D. R., \& Schmitt, K. L. (2002). Television and reality: Toddlers' use of visual information from video to guide behavior. Media Psychology , 4, 51-76.

Clark, R. C., \& Mayer, R. E. (2003). E-Learning and the science of instruction: Proven guidelines for consumers and designers of multimedia learning. San Francisco: JosseyBass/Pfeifer. A Wiley Imprint.

Copley, J. (2007). Audio and video podcasts of lectures for campus-based students: Production and evaluation of student use. Innovations in Education and Teaching International , 44, 387-399.

Cottingham, C. D. (1986). Limited edition: Small community colleges adapt to new technologies. New directions for community colleges, 1986, 59-64.

DeLoache, J. S., \& Nada, K. (2003). Special Section: Children and television video-based learning by very young children. Developmental Science, 3, 245-246.

Demetriadis, S., \& Pombortsis, A. (2007). E-Lectures for flexible learning: A study on their learning efficiency. Educational Technology \& Society , 10, 147-157.

Evans, P. (1995). Teaching undergraduate accounting students using videos and computer technology. Department of Accountancy Working Papers , no. 32.

Evans, P., \& Foster, E. (1997). Teaching accounting to overseas MBA students: Exploring an alternative method. Accounting Education , 6 (3), 231-245.

Houston, C. (2000). Video usage and active learning strategies among community college faculty members. Community College Journal of Research and Practice , 25 (5), 341357. 
Jadin, T., Gruber, A., \& Batinic, B. (2009). Learning with E-lectures: The meaning of learning strategies. Educational Technology \& Society , 12 (3), 282-288.

Littlefield, D. (1994). Open learning by PC or paper? Personnel Management , 26 (9), 55-58.

Martin, E., Evans, P., \& Foster, E. (1995). The use of video in the teaching of accounting. Accounting Education , 4 (1), 77-86.

Mullins, B., \& Mullins, B. (1994). The human side of technology. Canadian Insurance Journal , 4, 99.

Schwan, S., \& Riempp, E. (2004). The cognitive benefits of interactive videos: learning to tie nautical knots. Learning and Instruction , 14 (3), 293-305.

Smeltzer, D. K. (1988). Media utilization and the student-content teaching inventory : A correlation study of community college instructors. International Journal of Instructional Media (15), 222-223.

The State of North Carolina. (n.d.). Data Wearhouse. Retrieved 03 13, 2011, from North Carolina Community College System Data Warehouse: http://www.ncccs.cc.nc.us/training/datawarehousetraining/data_warehouse.html

Ueckert, C. W., \& Gess-Newsome, J. (2008). Active learning strategies: Three activities to increase student involvement in learning. The Science Teacher , 75 (9), 47-52.

Wetzel, C. D., Radtke, P. H., Stern, H. W., \& Biner, P. M. (1995). Instructional Effectiveness of Video Media. The American journal of distance education. , 9 (3), 81-82.

Zhang, D., Zhou, L., Briggs, R. O., \& Nunamaker Jr., J. F. (2006). Instructional video in elearning: Assessing the impact of Learning and Instruction interactive video on learning effectiveness. Information \& Management , 43 (1), 15-27. 


\section{APPENDICES}

\section{Appendix A - Class Syllabus}

Blue Ridge Community College

3D Modeling

SGD 114-301

Course Prerequisite(s): None

Co-requisite(s): None

Credit Hours for the Course: 3

Contact Hours for the Course: Tuesday 3:00PM - 4:15PM, TEDC, Room 114

Thursday 3:00PM - 4:15PM, TEDC, Room 114

Course Description: This course introduces the tools required to create three-dimensional (3D) models. Emphasis is placed on exploring tools used to create 3D models. Upon completion, students should be able to create and animate 3D models using 3D modeling tools.

Course Goals/Objectives:

(1) Development or enhancement of an understanding of simulation and game development problems, issues and challenges in line with the program's emphasis on portfolio quality work and continuous personal improvement and innovation.

(2) Creation of practical learning opportunities to improve student's ability to plan, execute and successfully complete a project. In addition, an appreciation and understanding of the limitations and pitfalls associated with project management may be discovered.

(3) Enhancement of the student's sensitivity for the human dimension of a project and the need for teamwork to ensure success.

Student Learning Outcomes:

The student will...

define, describe, and use the basic modeling, texturing, lighting and rendering techniques

associated with modeling in Maya.

critically examine and critique both peer and professional work.

produce portfolio quality renders in Maya.

Required Materials and Supplies: USB Flash Drive - 1 GB Minimum.

Reference Materials: None

Evaluation Policies and Procedures

Grading Policy:

Critique/Participation: $15 \%$

Midterm: 25\%

Final: 30\%

Assignments: $30 \%$ 
Due to the competitive nature of the gaming industry, assignment grades are awarded based on performance relative to all other individuals rather than performance relative to an absolute standard.

Students are required to take a non-graded pre and post test in Moodle.

All assignments are due Sunday before midnight.

All assignments are to be turned in via Moodle unless otherwise indicated. Internet issues will not be accepted as an excuse.

All assignments must include correct file structure and proper use of naming conventions. Late or incorrect files will not be accepted!

Grading Scale:

A: 93-100, B: 85-92, C: 77-84, D: 70-76, F: < 69

Classroom Policies

Attendance Policy: Regularity of class attendance is necessary in order to achieve maximum benefits from the program offered and for maintenance of a satisfactory academic record. Whenever students' attendance or punctuality endangers their own success or that of other students, they may be dropped from the course. Two tardies constitute one contact hour absence. Students will normally be dropped after they have accumulated absences exceeding 10 percent of the scheduled contact hours for the semester. The instructor may make exception in cases of extenuating circumstances such as disabling accident or illness. A student is expected to confer with each instructor before anticipated or after unavoidable absences. The responsibility of making up class work rests entirely with the student.

Academic Honesty: Blue Ridge Community College operates under the premise of academic honesty. The policy is that plagiarism and cheating are prohibited. Whereas it is the instructor's responsibility to create an environment in which academic honesty is expected, it is the student's obligation to uphold this policy.

Students who violate the academic honesty policy, either directly or indirectly, are immediately responsible to the instructor of the course. The instructor has the authority to assign an "F" or a "zero" for the exercise or examination or to assign an "F" in the course. If the course serves as a prerequisite for sequential courses within the curriculum, the student will not be able to progress in the program of study until completing the course with a passing grade.

For the purpose of this policy the following terms are defined:

Cheating: To practice or attempt to practice dishonesty or deception in the taking of tests or in the preparation or submission of academic work purporting to be one's own; or to do any of the following without instructor permission: to copy or attempt to copy from another person's test, paper, or other graded work in a course; to allow someone to copy one's test, paper, or other graded work; to use during a testing period, or bring into a testing area with the intent to use, any notes or other materials which a student is not permitted to consult.

Plagiarism: The act of copying a sentence, several sentences, or a significant part of a sentence that has been written by someone other than the person submitting the paper, and then neglecting to indicate through the use of quotation marks or blocking that the material has been copied; 
also, copying from another writer in such a way as to change one or two words in the sentence, or to rearrange the order of the wording, or to paraphrase, or to summarize information and then neglect to furnish documentation. Failure to cite sources when appropriate is a form of dishonesty.

The acts of cheating and/or plagiarism shall encompass, but shall not be limited to the examples or context cited above.

Disability Policy: Students who have a documented disability or who suspect that they may have a disability/learning problem can contact the Disability Services Office in Sink, Room 127 or call 694-1813/1812 to request accommodations.

Additional Policy/Policies:

Instructor reserves the right to change the syllabus as needed.

Cell Phone Policy - must be kept on vibrate, calls may not be answered in class, no texting. Internet Policy - while in the lab, internet use is restricted to websites that pertain to class work and/or projects. 
Appendix B - Project Rubric

\section{Modeling Project Rubric}

\begin{tabular}{|c|c|c|c|c|c|c|}
\hline \multicolumn{7}{|l|}{ Assignment: } \\
\hline & $\begin{array}{l}\text { Failure: } \\
\text { 0-2 point }\end{array}$ & $\begin{array}{l}\text { Novice: } \\
\text { 3-5 Points }\end{array}$ & \begin{tabular}{|c|} 
Intermediate: \\
6-8 points \\
\end{tabular} & \begin{tabular}{|c|} 
Mastery: \\
9-10 points
\end{tabular} & \begin{tabular}{|c|} 
Self \\
Evaluation
\end{tabular} & \begin{tabular}{|c|} 
Teacher \\
Evaluation \\
\end{tabular} \\
\hline $\begin{array}{c}\text { Content, } \\
\text { Composition } \\
\text { and Design }\end{array}$ & $\begin{array}{l}\text { Work subject } \\
\text { is not } \\
\text { appropriate. }\end{array}$ & $\begin{array}{l}\text { Work subject } \\
\text { is elementary } \\
\text { and shows } \\
\text { minimal } \\
\text { grasp of } \\
\text { course } \\
\text { concepts. }\end{array}$ & $\begin{array}{l}\text { Work subject } \\
\text { is adequate } \\
\text { and shows } \\
\text { moderate } \\
\text { grasp of } \\
\text { course } \\
\text { concepts. }\end{array}$ & $\begin{array}{l}\text { Work subject } \\
\text { is excellent } \\
\text { and shows } \\
\text { excellent } \\
\text { grasp of } \\
\text { course } \\
\text { concepts. }\end{array}$ & & \\
\hline $\begin{array}{c}\text { Technical } \\
\text { Requirements } \\
\text { Weight } 20 \%\end{array}$ & $\begin{array}{l}\text { Work does } \\
\text { not meet any } \\
\text { of the } \\
\text { project's } \\
\text { technical } \\
\text { requirements. }\end{array}$ & $\begin{array}{l}\text { Work barely } \\
\text { meets all of } \\
\text { the project's } \\
\text { technical } \\
\text { requirements. }\end{array}$ & \begin{tabular}{|l} 
Work \\
adequately \\
meets all of \\
the project's \\
technical \\
requirements.
\end{tabular} & $\begin{array}{l}\text { Work } \\
\text { exceeds all } \\
\text { of the } \\
\text { project's } \\
\text { technical } \\
\text { requirements. }\end{array}$ & & \\
\hline $\begin{array}{l}\text { Mechanics } \\
\text { Weight 20\% }\end{array}$ & $\begin{array}{l}\text { Includes } \\
\text { more than } 5 \\
\text { technical } \\
\text { errors, } \\
\text { naming, } \\
\text { clipping, etc. }\end{array}$ & $\begin{array}{l}\text { Includes 3-4 } \\
\text { technical } \\
\text { errors, } \\
\text { naming, } \\
\text { clipping, etc. }\end{array}$ & $\begin{array}{l}\text { Includes 2-3 } \\
\text { technical } \\
\text { errors, } \\
\text { naming, } \\
\text { clipping, etc. }\end{array}$ & $\begin{array}{l}\text { Work } \\
\text { includes no } \\
\text { technical } \\
\text { errors. }\end{array}$ & & \\
\hline $\begin{array}{c}\text { Aesthetics } \\
\text { Weight 20\% }\end{array}$ & $\begin{array}{l}\text { Work shows } \\
\text { a poor grasp } \\
\text { of aesthetic } \\
\text { concepts. }\end{array}$ & $\begin{array}{l}\text { Work shows } \\
\text { a minimal } \\
\text { grasp of } \\
\text { aesthetic } \\
\text { concepts. }\end{array}$ & $\begin{array}{l}\text { Work shows a } \\
\text { moderate } \\
\text { grasp of } \\
\text { aesthetic } \\
\text { concepts. }\end{array}$ & $\begin{array}{l}\text { Work shows } \\
\text { an excellent } \\
\text { grasp of } \\
\text { aesthetic } \\
\text { concepts. } \\
\end{array}$ & & \\
\hline $\begin{array}{l}\text { Storyboard } \\
\text { Weight } 10 \%\end{array}$ & $\begin{array}{l}\text { Storyboard } \\
\text { does not } \\
\text { accurately } \\
\text { portray the } \\
\text { work. }\end{array}$ & $\begin{array}{l}\text { Storyboard } \\
\text { barely } \\
\text { portrays the } \\
\text { work. }\end{array}$ & $\begin{array}{l}\text { Storyboard } \\
\text { adequately } \\
\text { portrays the } \\
\text { work. }\end{array}$ & $\begin{array}{l}\text { Storyboard } \\
\text { accurately } \\
\text { portrays the } \\
\text { work. }\end{array}$ & & \\
\hline $\begin{array}{c}\text { Growth and } \\
\text { Progress } \\
\text { Weight } 10 \%\end{array}$ & $\begin{array}{l}\text { Work does } \\
\text { not show any } \\
\text { growth from } \\
\text { previous } \\
\text { work. }\end{array}$ & $\begin{array}{l}\text { Work shows } \\
\text { minimal } \\
\text { growth from } \\
\text { previous } \\
\text { work. }\end{array}$ & $\begin{array}{l}\text { Work shows } \\
\text { adequate } \\
\text { growth from } \\
\text { previous } \\
\text { work. }\end{array}$ & $\begin{array}{l}\text { Work shows } \\
\text { significant } \\
\text { growth from } \\
\text { previous } \\
\text { work. }\end{array}$ & & \\
\hline \multicolumn{7}{|l|}{$\begin{array}{l}\text { Instructor } \\
\text { Comments }\end{array}$} \\
\hline & & & & Total Points & & \\
\hline
\end{tabular}


Appendix C - Assignment List

\begin{tabular}{|c|c|}
\hline Assignment & Student Learning Objectives \\
\hline Helm & $\begin{array}{l}\text { 1. Use 2D image planes as a reference for constructing 3D models. } \\
\text { 2. Use 3D primitives as the basis for creating more complex models. } \\
\text { 3. Smooth a polygon mesh. } \\
\text { 4. Create polygon faces by placing vertices. } \\
\text { 5. Split vertices and subdivide polygonal faces. } \\
\text { 6. Combine separate meshes into one mesh. } \\
\text { 7. Bridge between meshes. } \\
\text { 8. Add faces to an existing mesh. } \\
\text { 9. Use Snap to Grid. } \\
\text { 10. Preview a smoothed high resolution version of a polygon mesh. } \\
\text { 11. Harden and soften polygon edges. }\end{array}$ \\
\hline Biped & $\begin{array}{l}\text { 1. Create a basic biped character. } \\
\text { 2. Use the Mirror Geometry tool. } \\
\text { 3. Recognize naturally occurring edge loops in the biped figure. } \\
\text { 4. Recreate naturally occurring edge loops in the biped figure. } \\
\text { 5. Use the Merge and Merge to Center tools. }\end{array}$ \\
\hline Final & $\begin{array}{l}\text { 1. Create a unique work that can be added to a professional portfolio. } \\
\text { 2. Create a unique work with minimal instructor guidance. } \\
\text { 3. Use all skills developed in the class in conjunction with one another. } \\
\text { 4. Creatively solve problems, through research, or work around to } \\
\text { complete the project. } \\
\text { 5. Prepare professional quality presentation. }\end{array}$ \\
\hline
\end{tabular}




\section{VITA}

\section{RICHARD SYKES}

Education:

Professional Experience:
Public Schools, New Port Richey, Florida

B.A. Business Management, Eckerd College, St. Petersburg, Florida 2005

M.S. Engineering Technology, East Tennessee State University, Johnson City, Tennessee 2012

Honors and Awards: Who's Who in American Colleges 